Global and Stochastic Analysis

Vol. 5 • No. 6 • Special Issue 2018

\title{
MICE TOURISM DEVELOPMENT - EXAMINATION FROM THE SUPPLY SIDE IN DALAT CITY, VIETNAM
}

\author{
HA NAM KHANH GIAO - LE THAI SON
}

\begin{abstract}
The research attempted to examine resource factors affecting the development of MICE at Dalat, by determining the stakeholders, and by interviewing 350 resources (means from the supply side). The methods of Cronbach's Alpha, Exploratory Factor Anaalysis (EFA), Confirmatory Factor Analysis (CFA) together the Structural Equation Modelling (SEM) were used by the programs of SPSS and AMOS.

The result shows that MICE development is affected by MICE destination resources, then MICE destination resources is affected by 3 main factors, arranged by the importance decreasing: (1) Organization resources; (2) MICE tourist resources; (3) Supplier resources. From that, the research raises some solutions for management and policy makers to develop MICE better.
\end{abstract}

\section{Introduction}

\section{MICE concept}

MICE is an acronym for Meeting, Incentive, Conference and Exhibition, which is widely used in Asia and North America (Dwyer \&ctg, 2001). Australia uses the concept of business events; Canada uses the acronym MC and IT (Meetings, Conventions \& Incentive Travel) (Rogers, 2003). According to UNWTO (2006), the industry conference (commonly used in Europe) consists of the main components of MICE.

MICE tourism has the following important characteristics: (1) high growth potential, (2) high added value, and (3) high renewal benefits. With these characteristics, countries around the world are focusing on developing MICE tourism as a national economic recovery (Janakiraman, 2012). According to the UNWTO, in the convention sector, the ICCA said there were about 11,505 conferences seminars held annually around the world, spending about $\$ 280$ million, creating value for stakeholders. Approximately $\$ 1.16$ billion (in which the conference is $\$$ 0.4 billion and the exhibition is $\$ 0.76$ billion). The MICE tourism industry offers tremendous economic benefits to the host country and city hosting the event.

Vietnam is now an attractive destination for domestic and foreign tourists thanks to the well-known natural heritage recognized by UNESCO. By 2016, 747 hotels, resorts from 3 to 5 stars with 82,325 rooms, many international convention and exhibition centers had been operating (VNAT, 2016). Infrastructure for tourism has rapidly improved, transport infrastructure has developed rapidly, more

Keywords: MICE destination resources, MICE tourist resources, MICE tourism development, Organization resources, Supplier resources. 
international routes have been established, and airports are expanded to meet the needs of visitors and arrivals. According to the Vietnam National Administration of Tourism in 2016, the number of international visitors to Vietnam was 10,012,735 (of which, about $7 \%$ are MICE tourists), with a total revenue of 400 trillion VND. ICCA (2016) said that Vietnam had held 48 major conferences. Therefore, Vietnam is more likely to develop MICE tourism.

\section{MICE tourism research situation}

Research on MICE tourism mainly uses destinations as a main research unit for local development in general, tourism development in particular and focus on MICE tourism development. Denicolai et al. (2010) suggested that in order to develop tourism at a destination, attention should be paid to the network relationships of tourism companies and the development of the core competencies of tourism of local resources and travel capacity of that destination. Bennett et al. (2010) showed that policies such as transparency, co-operation, and consistency are effective in achieving the goals and objectives of the destination, or the needs of the parties concerned. González and Falcón (2003) argued that in order to have a successful travel destination for a type of tourism, it is necessary to consider the resources of the destination. Nakatani and Teixera (2009) focused on proposing and managing tourism policies, managing tourism-related entities to generate tourism development of destinations, the role and involvement of public, private, supplier, and other stakeholders must be clear and service quality must also be concerned to create tourism development.

In developing countries, MICE tourism is being emphasized. In China, except for the famous MICE cities such as Beijing, Shanghai, other cities with advantage of tourism are focusing on research to develop MICE tourism such as Harbin, Heilongjiang Jiang, Tangshan, Kaifeng ... Mauritius, an island nation in the Indian Ocean, has been researched by Seebaluck et al. (2013) for the opportunities of cooperation and the challenges of MICE tourism development. Dinoviæ (2010) examined the successful experiences of MICE destinations applied for Montenegro, showing that the involvement of all stakeholders in the provision of resources for the formation of alternative tourism products has a difference in quality over the current form. Ramgulamet al. (2012) applied the Australian MICE tourism development experience to study the development of the MICE market in Trinitrat\& Tobago.

In Vietnam, there are very few in-depth studies on MICE tourism at large scale. Researches are only at the basic application level of MICE tourism for a locality, destination or for a local business such as Danang City, at 4-star hotels in Ha Long - QuangNinh; in HoChiMinh City, HaiPhong; Enterprises such as Saigontourist Company, Indovina service and Vietnam Tourism Company in Hanoi. Nguyen Chi Tranh (2014) based on real challenges such as undeveloped infrastructure, the development of MICE tourism spontaneously, tourism promotion is still not worth the potential, tourism products are still ambiguous, and the human resources are lacking, weak in MICE tourism. Resolution No. 08-NQ/TW of the Politburo dated January $16^{\text {th }}, 1977$ clearly stated the viewpoint of tourism development is to 
become a spearhead economic sector, a strategic direction for the country's economic development, and accelerate the development of other branches and domains. Therefore, the study of MICE tourism in Vietnam is very necessary. MICE tourism has the following important characteristics: (1) high growth potential, (2) high added value, and (3) high renewal benefits. With these characteristics, countries around the world are looking to develop MICE tourism as a national economic recovery (Janakiraman, 2012). Many studies on MICE tourism showed that attention needs to be paid to the network relationships of tourism companies, considering the resources of the destination to develop the core competencies of tourism of the resources, capabilities and the destination with the participation of all stakeholders in the provision of resources to form tourism products that have a difference in quality than the current form (Denicolai et al., 2010; González and Falcón, 2003; Đinoviæ, 2010); Le Thai Son and Ha Nam KhanhGiao (2014) developed a model of MICE tourism development, testing the model from MICE tourists. The results show that the destination resources are supported by the stakeholders and have the same impact on the development of MICE tourism in Da Lat. However, the model should be further examined and verified from the current support. From there, assess the suitability of the MICE tourism development model at a MICE destination in Vietnam as compared to the overseas studies.

In this study, Dalat was chosen as a MICE tourist destination to test the suitability of the MICE tourism development model in Vietnam because: (1) Dalat fulfills two conditions: on basic elements such as natural resources, human resources, climate, geographic location; and on advanced elements including improved transport infrastructure and digital data communications, basic human resources to meet the needs and research institutes of the faculties. (2) Dalat considers transforming the tourist operation model to the promotion of MICE tourism and it is a trend which is suitable to the world in the direction of sustainable tourism development (Đinovíc, 2010), (3) Dalat is increasingly chosen to hold more conferences, seminars at governmental levels, associations and sectors, (4) a quick survey with 400 Visitors to MICE activities in Dalat accounted for $56.6 \%$ compared to $43.4 \%$ of visitors.

\section{Literature and Research Model}

\section{Theoretical base}

Michell et al. (1997) studying stakeholders suggested that: "Stakeholders can be identified by their possession or attributed possession of one, two, or all three of the following attributes: (1) the stakeholder's power to influence the firm, (2) the legitimacy of the stakeholder's relationship with the firm, and (3) the urgency of the stakeholder's claim on the firm." If relevant parties only own a property, they are called the underlying stakeholders; If they own two characteristics, they will be known as expectation stakeholders; and with three characteristics, they are socalled clear stakeholders. Stakeholders are often considered as: (1) Destination Management Organization (DMO); Customer visite Bureau (CIB) which are often referred to as professional organizations, managers; (2) Operators, organizers, sponsors are considered separately in each research context; (3) Marketing mediation is usually a bridge between the supplier and the destination or the tourist of 
destination; (4) MICE tourists; (5) MICE destinations; (6) Residental community and (7) Government.

Resource-based theories (Acedo et ctg, 2006) include: a resource-based view each independent organization has its own resource structure, namely, physical assets, and its own possessiveness and / or control, which is inherent in its origins; knowledge-based view - changes in the business environment will affect both supply and demand (Cooper, 2006), so destinations must continually adapt by creating , using the knowledge needed to respond to change; and relational view - when participating in a new network, the capacity of each stakeholder will grow stronger, which is also true for a destination.

\section{The relationship between MICE tourism development and resource factors}

\section{Impact from supplier resources to $M I C E$ destination resources}

All MICE events require the provision of a variety of activities such as domestic and international transportation through travel agencies and companies; Accommodation of delegations, guests; convention center; exhibition hall; audiovisual services at high-end hotels and resorts are an important components of the MICE package service. In addition to the physical resources, the supplier can also provide additional resources and networking knowledge. The stronger the source is, the more MICE destination to develop.

$$
H_{1} \text { : Supplier resources have a positive impact on MICE destination resources }
$$

\section{The impact of the organizers' resources on the MICE destination resources}

Organizers use their credibility, brand of destination, their ability (tangible and intangible resources) to host and organize events, attract more resources to develop destinations (Tingting et al., 2007). Governments are often important organizers and donors to organize MICE activities to attract experts, domestic and foreign tourists. Professional associations and non-profit organizations often use this activity to train, promote market development, transfer scientific research results, etc. Large companies, multinational companies also often hold MICE activities which target to the needs of MICE visitors.

$$
H_{2} \text { : Resources Organizers have a positive impact on MICE destination resources. }
$$

\section{The impact of professional organizational resources on MICE destination resources}

In developed countries in Europe, America, some Asian countries like Japan, Korea, Singapore ... professional organizations have contributed greatly to the successful organization of a MICE event. Professional organizations can assist MICE destination resources based on knowledge and relationship-based resources, they rely on their skills and experience to increase the amount of information needed and important for MICE tourists. In addition to the experience, networking of professional organizations and other stakeholders, such as organizers, suppliers and visitors, has been strengthened through successful events in the past. 
$H_{3}$ : Professional organizational resources have a positive impact on MICE

destination resources.

The impact of MICE tourist resources on MICE destination resources

Many authors have suggested that MICE visitors are defined as employees or sponsors of MICE-based companies both domestically and internationally or have participated in MICE activities (Cook et al., 2006). Engines are one of the key components that explain what travelers are looking for and how to meet them (Fodness, 1994). MICE visitors spend not only on hotels, restaurants but also in the field of entertainment, exploring new cultures ... Campiranon and Arcodia (2008) showed that MICE visitors spend 3 times higher than normal visitors. This has helped to facilitate foreign exchange and create more employment opportunities (Dwyer et al., 2001).

$H_{4}:$ MICE visitors' resources have a positive impact on MICE destination resources.

Relationship between MICE destination resources and MICE tourism development

The development of tourism in general, MICE tourism in particular must be based on the destination resources and the influence resources. According to Kotler et al. (1999), in order to develop the local economy in general, to develop a sector in particular, it is necessary to maintain existing manufacturing sectors, build the tourism industry, develop the network to the outside, and attract external investors to have new resources for investment and development. Hussain et al. (2012) showed that the three sectors are tourism information, MICE visitors' spending, and MICE individual and group visitors' experience on rising events.

\section{$H_{5}: M I C E$ destination resources have a positive impact on the development of} MICE tourism.

\section{Recommended research model}

The above-mentioned hypotheses are also based on a model of factors affecting the development of MICE tourism in Dalat (Le Thai Son and Ha Nam Khanh Giao, 2014), there is a relationship between the resources of suppliers, organizers, organizations, MICE visitors with MICE destination resources. The proposed model is shown in Figure 1.

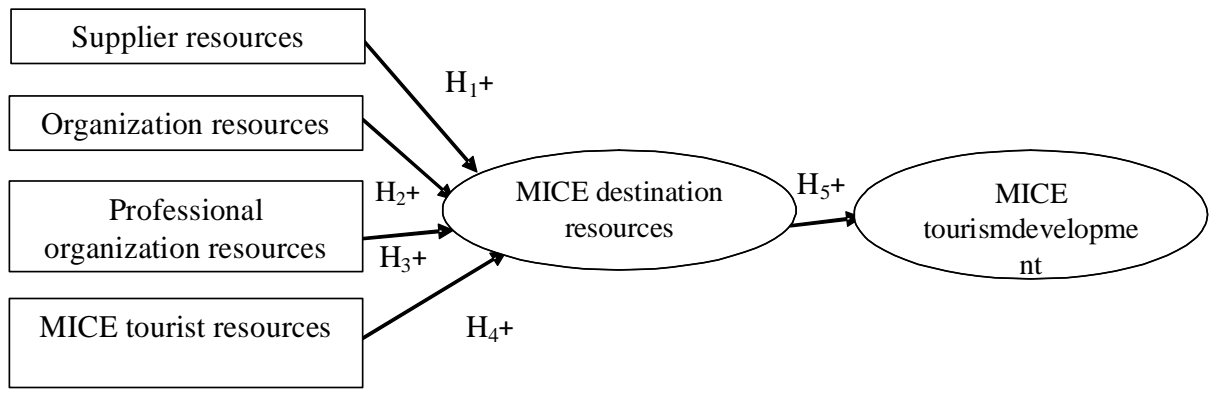

Figure 1: MICE tourism development suggested model 


\section{Research Methodology}

\section{Qualitative and quantitative preliminary research}

After reviewing the resource-based theory, the theory of development for the synthesis of related metrics, the author group had a group discussion with 11 experts in this field to develop a preliminary scale and create a questionnaire. A preliminary survey was conducted with 100 respondents from 35 MICE tourism organizations, together with reliability testing, and exploratory factor analysis to test preliminary results. Then, consulted with 11 experts the second time to adjust the wording for the questionnaire to make it easy to understand and appropriate.

The results of the supplier resource scale $(\mathrm{S})$ has 5 observed variables; Organization resource scale $(\mathrm{O})$ has 4 observed variables; The professional organization resource scale (A) has 5 observed variables; The MICE tourist resource scale $(\mathrm{T})$ has five observed variables; MICE destination resource scale (D) has 7 observed variables; The MICE tourism development (APT) has 6 variables.

\section{Quantitative research}

The official scale of the research concepts was formed, consisting of 32 statements, measured on the Likert 5 ranging from $1=$ totally disagree to $5=$ totally agree. SPSS 20 and AMOS, EFA, CFA, SEM are used.

\section{Research Results}

\section{About the sample}

The total number of questionnaires was 400 , and 350 samples were collected. There were 65 rejected questionnaires, resulting in 285 valid questionnaires $(71.25 \%)$ for the official study. Table 1 shows the sample statistics.

Table 1

Summary of survey sample characteristics

\begin{tabular}{llcc}
\hline \multicolumn{2}{c}{$\begin{array}{c}\text { Sample characteristics } \\
\text { (sample size }\end{array}$ = 285) } & Quantity (person) & Percentage (\%) \\
\hline Position of the & General Director & 166 & 58,2 \\
interviewee & Sales Director & 58 & 20,4 \\
& Specialist & 61 & 21,4 \\
& Total & 285 & 100,0 \\
Years in MICE & 1-2 years & 81 & 28,4 \\
tourism & 3-4 years & 69 & 24,2 \\
& Th years & 135 & 47,4 \\
& Total & 285 & 100,0 \\
\hline
\end{tabular}

(Source: Measured by the authors) 
Reliability test and exploratory factor analysis results

Table 2

Cronbach's Alpha scale results

\begin{tabular}{llcccc}
\hline No. Scales & Symbols & $\begin{array}{c}\text { No. of } \\
\text { Observed } \\
\text { variables }\end{array}$ & $\begin{array}{c}\text { Cronbach's } \\
\text { Alpha } \\
\text { coefficient }\end{array}$ & $\begin{array}{c}\text { Smallest } \\
\text { Item-total } \\
\text { correlation }\end{array}$ \\
\hline 1 & Supplier resources & $\mathrm{S}$ & 5 & 0.856 & 0.565 \\
2 & Organization resources & $\mathrm{O}$ & 4 & 0.788 & 0.567 \\
3 & Professional Organization resources & $\mathrm{A}$ & 5 & 0.778 & 0.471 \\
4 & MICE tourist resources & $\mathrm{T}$ & 3 & 0.730 & 0.405 \\
5 & MICE destination resources & $\mathrm{D}$ & 7 & 0.840 & 0.510 \\
6 & MICE tourism development & $\mathrm{PT}$ & 7 & 0.875 & 0.588 \\
\hline
\end{tabular}

(Source: Measured by the authors)

Table 2 shows that these scales have high Cronbach's Alpha coefficients (range from 0.730 to $0.875>0.6$ ), ensuring reliability. $\mathrm{KMO}$ and Barlett testing for the $\mathrm{KMO}$ coefficient and Barlett's mean value for sig. $=0.000<0.05$. All observed variables of this scale have aitem- total coefficient of correlation greater than 0.3 , so they are used for subsequent EFA.

The EFA method is used for 17 observed variables, using the Principal Component Analysis method with Varimax rotation and the stoppage when extracting the Eigenvalues elements. The results of the EFA with the remaining 17 observed variables, KMO coefficient $=0.827>0.5$ which is satisfactory, explaining the appropriate sample size for factor analysis and the Barlett coefficient with Sig $=0.000<0.5$ (correlation between variables) confirms that the above analysis method is appropriate. The average variance extracted is $56.612 \%(>50 \%)$ which means 17 extracted observed variables explain about $56.612 \%$ of the variability of observed variables and factor loadings are greater than 0.5 , which is satisfactory (Table 3).

Table 3

Results of factor analysis for independent variables

\begin{tabular}{lcccc}
\hline & \multicolumn{3}{c}{ Factor } \\
\cline { 2 - 4 } & 1 & 2 & 3 & 4 \\
\hline $\mathrm{S}_{1}$ & 0.854 & & \\
$\mathrm{~S}_{2}$ & 0.759 & & \\
$\mathrm{~S}_{3}$ & 0.728 & & \\
$\mathrm{~S}_{4}$ & 0.765 & & \\
$\mathrm{~S}_{5}$ & 0.573 & & 0.703 \\
$\mathrm{O}_{1}$ & & & 0.758 \\
$\mathrm{O}_{2}$ & & & 0.662 \\
$\mathrm{O}_{3}$ & & & 0.683 \\
$\mathrm{O}_{4}$ & & & contd. table 3
\end{tabular}




\begin{tabular}{lcccc}
\hline & \multicolumn{4}{c}{ Factor } \\
\cline { 2 - 5 } & 1 & 2 & 3 & 4 \\
\hline $\mathrm{A}_{1}$ & & 0.824 & & \\
$\mathrm{~A}_{2}$ & 0.750 & & \\
$\mathrm{~A}_{3}$ & & 0.720 & & \\
$\mathrm{~A}_{4}$ & & 0.646 & & \\
$\mathrm{~A}_{5}$ & & 0.716 & 0.601 & \\
$\mathrm{~T}_{1}$ & & & 0.728 & \\
$\mathrm{~T}_{2}$ & & & 0.720 & \\
$\mathrm{~T}_{3}$ & & & 0.680 & \\
$\mathrm{~T}_{4}$ & & & 0.669 & 1.388 \\
$\mathrm{~T}_{5}$ & & & & \\
Accumulated variance (\%) & 26.885 & 41.772 & 1.431 & 0.717 \\
Eigenvalue & 5.108 & 2.828 & 0.768 & \\
Reliability & 0.838 & 0.790 & & \\
\hline
\end{tabular}

(Nguồn: Kếtquảxủlýtùddũliệuiềutra)

The results of the dependent variables analysis with the 4 variables show that, with the principal component extraction method, Varimax rotation allows two factor with 13 observed variables and the average variance extractedof $75.448 \%$ $(>50 \%), \mathrm{KMO}$ coefficient $=0.877>0.5$ which is satisfactory, the Eigenvaluesare 5.034 and $2.302(>1)$, the factor loadings of coefficients of the observed variables are greater than $0.5=>$ satisfactory scale (Table 4 ).

Table 4

Results of factor analysis of dependent variablesMICE tourism development

\begin{tabular}{lcc}
\hline & & Factor \\
\cline { 2 - 3 } & 1 & 2 \\
\hline $\mathrm{D}_{1}$ & & 0.787 \\
$\mathrm{D}_{2}$ & & 0.643 \\
$\mathrm{D}_{3}$ & & 0.706 \\
$\mathrm{D}_{4}$ & & 0.740 \\
$\mathrm{D}_{5}$ & & 0.736 \\
$\mathrm{D}_{6}$ & & 0.648 \\
$\mathrm{D}_{7}$ & & 0.593 \\
$\mathrm{PT}_{1}$ & 0.616 & \\
$\mathrm{PT}_{2}$ & 0.800 & \\
$\mathrm{PT}_{3}$ & 0.835 & \\
$\mathrm{PT}_{4}$ & 0.806 & \\
$\mathrm{PT}_{5}$ & 0.812 & \\
$\mathrm{PT}_{6}$ & 0.766 & \\
Accumulated variance (\%) & 38.425 & \\
Eigenvalue & 5.034 & 2.302 \\
Reliability & 0.880 & 0.828 \\
\hline
\end{tabular}

(Source: Analysis results of the authors) 


\section{Confirmatory factor analysis}

When conducting the critical factor model analysis, it shows that the model result has 308 degrees of freedom, Chi-square $=494.328$ with $\mathrm{p}=0.000 ; \mathrm{GFI}=0.890$; $\mathrm{TLI}=0.932 ; \mathrm{CFI}=0.940 ; \mathrm{RMSEA}=0.046$ less than 0.06 . The confirmatory factor analysis with all indicators results suitable for the Multi-Sample Model, the scales satisfied the requirements to conduct SEM analysis. A summary of the results of the confirmatory factor analysis (CFA) is shown in Table 5.

Table 5

Summary of test results of the model

\begin{tabular}{lccccccc}
\hline Scales & Symbol Variables & Reliability & $\begin{array}{c}\text { Average } \\
\text { variance } \\
\text { extracted }\end{array}$ & $\begin{array}{c}\text { Factor } \\
\text { loading }\end{array}$ & Suitability \\
& & \multicolumn{9}{c}{$c$} & $\alpha$ & $\rho c$ & & \\
\hline Supplier resources & $\mathrm{S}$ & 5 & 0.838 & 0.834 & 0.507 & 0.703 & Suitable \\
Organization resources & $\mathrm{O}$ & 4 & 0.717 & 0.719 & 0.391 & 0.624 & Suitable \\
MICE tourist resources & $\mathrm{T}$ & 5 & 0.771 & 0.776 & 0.406 & 0.633 & Suitable \\
MICE destination resources & $\mathrm{D}$ & 7 & 0.828 & 0.832 & 0.418 & 0.641 & Suitable \\
MICE tourismdevelopment & $\mathrm{PT}$ & 6 & 0.880 & 0.875 & 0.54 & 0.732 & Suitable \\
\hline
\end{tabular}

(Source: Results from data collection)

The data in Table 5 shows that reliability and overall reliability are all obtained; the average variance extracted of organization resources, MICE tourist resources, and MICE destination resources is below 0.5, while factor loadings are high. This is also a limitation because the model was first tested theoretically. The formal theoretical model after the test is adjusted as shown in Figure 2.

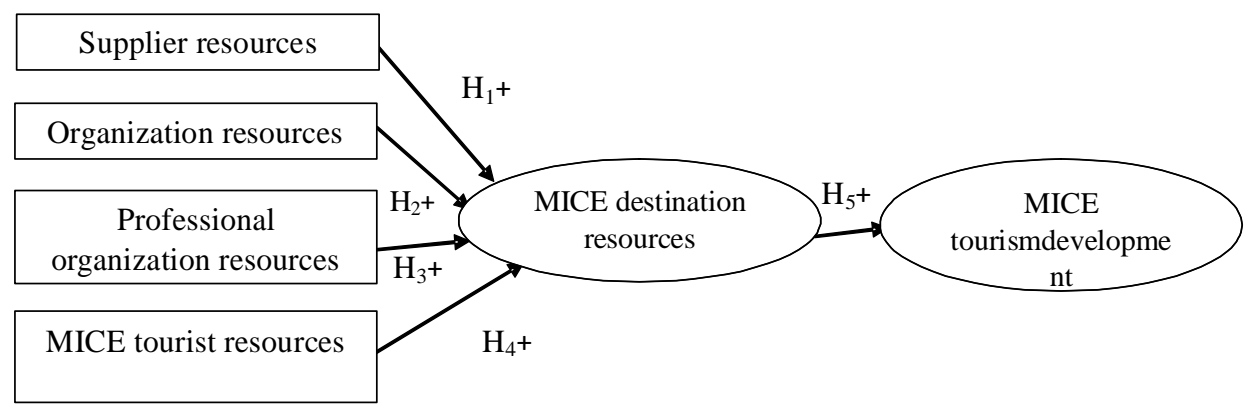

Figure 2: The formal theoretical model after verification 


\section{Verification of the formal theoretical model}

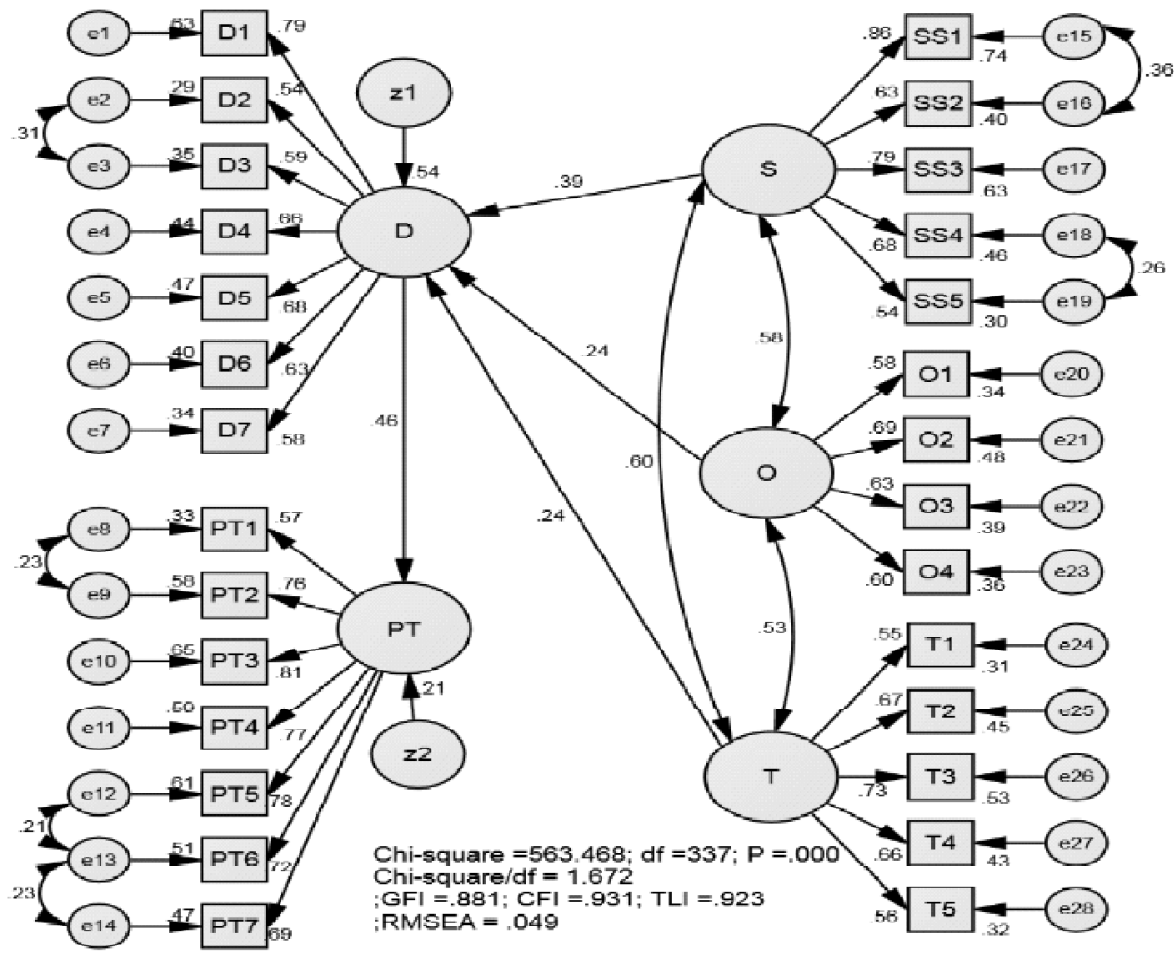

Figure 3: SEM results of standardized theoretical model

Examining the SEM model (Figure 3) shows that the model has 337 degrees of freedom, chi-square $=563.468(\mathrm{p}=0.000)$, Chi-square $/ \mathrm{df}=1.672$ is less than 2 ; Indicators: $\mathrm{GFI}=0.881$; TLI $=0.923$; CFI $=0.931$ and RMSEA $=0.049$ are less than 0.06. The results of the scale tests showed that the scales were reliable, the overall model fit statistics show that the model fits the data within established guidelines.

The standardized regression coefficients of the major parameters are presented in Table 6 showing that these relationships are positive from the groups of resource

Table 6

Standardized regression coefficients of the theoretical model

\begin{tabular}{lcccccc}
\hline & Correlation & & Estimation & S.E. & C.R. & $P$ \\
\hline Supplier resources & $\rightarrow$ & MICE destination & 0.385 & 0.053 & 11.727 & 0.0000 \\
Organization resources & $\rightarrow$ & MICE destination & 0.241 & 0.055 & 13.733 & 0.0000 \\
MICE tourist resources & $\rightarrow$ & MICE destination & 0.24 & 0.055 & 13.762 & 0.0000 \\
MICE destination & $\rightarrow$ & MICE tourism & 0.458 & 0.050 & 10.541 & 0.0000 \\
& & development & & & & \\
\hline
\end{tabular}

(Source: Results from data collection) 
factors that affect the destination resources and the destination resources have a positive impact on the development and they are all statistically significant ( $p$ $<0.05)$

\section{Conclusion and managerial implications}

This result confirms the suggested hypotheses are the supplier resources (S); organization resources (S); MICE tourist resources (T) have a positive impact on MICE destination resources(D). The strongest impact is the supplier resources, followed by the organization resources and the MICE tourist resources that have the same impact on the destination; and MICE destination resources also have a strong impact on MICE tourism development (PT).

From the impact of resource factors to the destination to create MICE tourism development, the authors propose the managerial implications shown in Figure 4.

Compared with the surveyed model from the visitors' points of view, the result has a difference and that is the professional organization resources factor has a negative impact and is not statistically significant at 5\%; this is also the limitation of the study. The model should continue to be tested at MICE destinations such as Ho Chi Minh City, Hanoi for further confirmation.

Table 7

Average values of resources and MICE tourism development

\begin{tabular}{lcr}
\hline & Mean & Standard deviation \\
\hline Supplier resources (S) & 3.2814 & 0.66975 \\
Organization resources (O) & 3.5009 & 0.72113 \\
MICE destination resources (D) & 3.6351 & 0.60267 \\
MICE tourist resources (T) & 3.4905 & 0.58702 \\
MICE tourism development (PT) & 3.9731 & 0.70479 \\
\hline
\end{tabular}

(Source: Results from data collection)

Table 7 shows means of factors by interviewees: means of resource factors for organizers, suppliers, MICE tourists, and destination resources range from 3.2814 to 3.6351. This result reflects MICE destinations are not many and diversified in supply resources and support to promote the development of MICE tourism. The interviewees' assessments of development were quite high with $\mathrm{PT}=3.9731$. This shows that the current destination has only exploited comparative and competitive advantages of its existing tourism resources to develop.

Regression results show that destination has a positive impact on development. The mobilization of resources from outside of the destination will increase the development of MICE tourism in the future. In addition, the resources of MICE tourists also contribute to the destination resources and contribute to the development. Thus, the correlation between MICE tourists' attraction to destinations and enabling them to contribute their resources when they participate in MICE activities will lead to a stronger MICE tourism development.. 


\begin{tabular}{|c|c|c|}
\hline $\begin{array}{l}\text { * Strengthening supply resources: } \\
\text { - Invest in tourism infrastructure in line } \\
\text { with the development trend; } \\
\text { - Invest in the development of modern } \\
\text { equipment and technologies to facilitate } \\
\text { the provision of services; } \\
\text { - Develop modern information network } \\
\text { infrastructure, network connection, and } \\
\text { internet; } \\
\text { - Develop an additional service } \\
\text { network; } \\
\text { - Develop the process of receiving and } \\
\text { transferring knowledge and experience } \\
\text { from related parties at the destination. } \\
\text { * Strengthening organizer resources: } \\
\text { - Focus on hosting and sponsoring } \\
\text { events for many types of events; } \\
\text { - Pay attention to relationships and } \\
\text { cooperation with organizations and } \\
\text { associations organizing events at the } \\
\text { destination; } \\
\text { - Pay attention to the role of } \\
\text { destination residents. } \\
\text { * Strengthen MICE tourist resources } \\
\text { - Attract more potential domestic and } \\
\text { foreign tourists; } \\
\text { - Organize a series of events related to } \\
\text { cultural exchanges and meeting with } \\
\text { residents to facilitate the exchange and } \\
\text { transfer of research results; } \\
\text { - Diversify high-end products and } \\
\text { services to attract MICE tourists. }\end{array}$ & $\begin{array}{l}\quad \text { MICE destination } \\
\quad \text { resources } \\
\text { - Have enough } \\
\text { places to eat, rest, } \\
\text { enjoy high quality } \\
\text { entertainment; } \\
\text {-Provide conference } \\
\text { rooms with high } \\
\text { standards; } \\
\text { - Have an exhibition } \\
\text { center, entertainment } \\
\text { center; } \\
\text { - Diversify tourism } \\
\text { products to attract } \\
\text { tourists; } \\
\text { - Continue training, } \\
\text { and enhancing } \\
\text { experience to } \\
\text { professionalism. }\end{array}$ & $\begin{array}{l}\quad \text { MICE } \\
\text { TourismDevelop } \\
\quad \text { ment }\end{array}$ \\
\hline
\end{tabular}

Figure 4: Managerial implications for MICE tourism development

\section{Managerial implications which are related to supplier resources}

The results show that $\beta S=0.399$ is the strongest determinant of destination resources. In the context of resource dependence, inadequate provision of resources from suppliers will cause the MICE destination to be inattractive and unable to attract visitors.

A destination often consists of many units, travel business organizations. Its resources are allocated through resources (tangible and intangible) and the capacity of the operational units, which is the resources of the destination represented in the integration, successful restructuring and allocation of the resources, the effective use of the capacity. Under the condition of a developing country today, it is difficult to have a destination that has the resources to create a complete support system for the event, thus continuing to integrate, reconstructing and attracting the suppliers will help the destination to mobilize both internal and external resources, creating a step-by-step supporting system. Therefore, the destinations will benefit from both: (1) the communication between the product and service of the destination and (2) the production of the service. In fact, the product is the level of destination, 
which means the package includes the facilities, the image of the destination, service, and quality of service, additional services and MICE tourism products. (Chon and Weber, 2002); Resources and capabilities are the abilities of the business unit, making it necessary for the units in the participating destination to process and produce together. Thus, the mobilization and use of distributed resources will be one of the most important resources in the capacity of the destination.

Table 8

Statistics of the means of supplier resources factor

\begin{tabular}{lcr}
\hline & Mean & $\begin{array}{r}\text { Standard } \\
\text { deviation }\end{array}$ \\
\hline $\begin{array}{l}\text { Investment in tourism infrastructure at the destination is in } \\
\text { accordance with MICE tourism }\left(\mathrm{S}_{1}\right)\end{array}$ & 3.0211 & 0.75029 \\
Easy to rent equipment, event service $\left(\mathrm{S}_{2}\right)$ & 3.2140 & 0.90760 \\
$\begin{array}{l}\text { There are many travel companies and travel agents involved in } \\
\text { providing transportation services for visitors to events at } \\
\text { destinations }\left(\mathrm{S}_{3}\right) \text {. }\end{array}$ & 3.4772 & 0.92138 \\
$\begin{array}{l}\text { There are conference service companies: advertising, audiovisual, } \\
\text { translation, rental of trees, souvenirs }\left(\mathrm{S}_{4}\right)\end{array}$ & 3.3965 & 0.84378 \\
$\begin{array}{l}\text { Organizational experience of large hotels and resorts makes the } \\
\text { MICE event a success }\left(\mathrm{S}_{5}\right)\end{array}$ & 3.2982 & 0.86327 \\
\hline
\end{tabular}

(Source: Results from data collection)

In supply resources, suppliers and intermediaries are often attracted by high spending by business travelers or MICE tourists. These people often have high demands and experiences, so quality of service is essential and crucial to them. One destination should have a specific plan and have an information exchange system about how the system participates (how many suppliers, services and products are provided) into the process of the event that will help the destination know clearly the resources it has, where to mobilize more, mobilize which suppliers, for what event. Thus, along with their comparative advantages, destinations will provide their target customers with the right event, the content in the event they expect to be involved.

Of the 5 variables of supplier resources proposed in this study, only variable $\mathrm{S}_{1}$ $=3.0211$ (Table 8) has a low mean, indicating that in the past, although the destination realized the improvement of infrastructure, transportation, information systems to facilitate the development of the local. However, the system of equipment, services for MICE tourism is not paid attention to investment, only at the basic, minimum level. It means that the event organizers and visitors are having difficulty renting equipment and services for their events. On the other hand, the connection between these services is not yet established and runs smoothly. Speeding up the connection, facilitating the rotation, exchanging of equipment and services from the event organizer with the service provider and the feedback will help improve the efficiency of the providers.

Variable $\mathrm{S}_{2}$ is currently underperforming at 3.2140 (Table 8 ), suggesting that the service companies for conferences, seminars and exhibitions have not supported 
much for the organizers. For advertising companies, audiovisual equipment rental, event decorators, they need to be provided quickly, promptly, and extensively so that more contractors can participate in the bidding and the organizers can choose the most efficient service provider.

The level of assessment of infrastructure investment at the destination is moderate, which means the suitability of the tourism infrastructure in the destination is not high. The destination needs to be continually reinvested and upgraded existing facilities in order to attract more organizers to the event, thus attracting more service providers to the destination. Variable $\mathrm{S}_{3}$ is currently rated at 3.4772 , which means that the level of participation in the transport, delivering tourists to the destination of travel companies, the travel agency is rated higher than the average, but still not good enough. This may be due to a lack of linkage between the destination and the above units. The result is that not many visitors come to the destination. Improving and expanding relationships in a collaborative, mutually beneficial manner will increase the engagement of visitors to MICE tourism destinations or other types of tourism.

The mean of the $\mathrm{S}_{4}$ variable is 3.3965, indicating that there are several, but not many tourist business units involved in providing visitor services such as advertising, souvenir shops, or these shops have similar products, not diversified. This does not create the convenience for visitors to choose the provider to make decision to attend the event for themselves. More attractive policies are needed to attract more and more business units to provide new addition services to visitors such as entertainment, shopping and other services. These services should be combined with the information network at the destination to provide visitors with choices.

The $\mathrm{S}_{5}$ variable is 3.2982 which is just above average, indicating the service and organizational support capabilities of high-end hotels, resorts and information systems are not strong enough. Increaing levels of network resource support, the experience of these hotels, combined with increaing information systems development among the relevant units in the destination will increase the impact of supplier resources to destination resources.

\section{Managerial implications related to MICE tourist resources}

The results show that $\mathrm{a} T=0.379$ is the second most potent factor affecting the destination. MICE tourists have a twofold impact on the destination, the first one is their contribution to increased destination growth through their costs; the second one is that they are the beneficiaries of the event products of services and contribute resources to increasing MICE tourism development. Therefore, in addition to paying attention to other factors, visitors must be targeted by the destination. With different visitors, the event will be different in terms of the form and content of the event. However, an important point to note is that MICE tourists are often in high demand and have a lot of travel experiences. Therefore, the quality of service must be taken first, not only at the destination but also at the supply chain. Many studies show that service quality is often measured by the satisfaction of the visitors, so the impact of satisfaction will be an important factor in determining the revisit 
intention of visitors. On the other hand, travel experience will help MICE tourists choose travel destinations.

Table 9 shows that the average value of each variable, from 3.4351 to 3.5579 , represents the contribution of MICE tourists to just above average. To let MICE tourists contribute indirectly to the development of tourism infrastructure, they are one of the beneficiaries of the promotion of the media, the news, and the images of the achievements in the field of tourism infrastructure from their indirect contributions through tourism costs. Current level is only 3.4386 .

Table 9

Statistics of the means of MICE tourist resources

\begin{tabular}{llr}
\hline & Mean & $\begin{array}{r}\text { Standard } \\
\text { deviation }\end{array}$ \\
\hline $\begin{array}{l}\text { Indirectly provide funding for tourism infrastructure (T1) } \\
\text { Increase connection between many other visitors with }\end{array}$ & 3.4386 & 0.62285 \\
$\begin{array}{l}\text { destination (T2) } \\
\text { Contribute to the transfer and dissemination of }\end{array}$ & 3.4351 & 0.87220 \\
research results (T3) & 3.5579 & 0.83980 \\
Contribute to cultural development at MICE destination (T4) & 3.5158 & 0.84582 \\
Increase quality of life for destination residents (T5) & 3.5053 & 0.86652 \\
\hline Source: Results from data collection) & &
\end{tabular}

The $\mathrm{T}_{2}$ variable shows that the connection between visitors who have attended MICE and other visitors is not high, with mean of 3.4351. This proves that MICE activities and other activities at the destination are not very attractive, so visitors do not have many entertainment options after attending the conference, the entertainment services may be less and monotonous. In order for MICE travelers to connect with more visitors, it is necessary to increase the capacity to provide and organize more attractive activities, to create a variety of entertainment services to meet the desires of MICE tourists at the destination to fascinate them.

The $T_{3}$ variable shows that the main contributing factor in MICE tourism is the ability to transfer and disseminate research results that are most appreciated by those interviewed. This is an important part of MICE activities that make up the MICE tourism development. The results of the disseminated research, transfer, and knowledge resources are publicized, the direct and indirect beneficiaries are increasing result in theachieved objectives of the conference and workshop. Increasing the transfer, dissemination of experience resources from individual visitors, the delegation will help the destination take advantage of this invisible resource to create future growth. For example, after the seminars on high-tech agriculture, participants in the conference should have a chance to visit vegetable gardens, flowers, and berries applying new technologies in cultivation and care; visit the cold storage packaging products standard for consumers, or visit protected areas of natural values to see the importance of the green environment to life. During this time, the experience, exchanges between professionals and residents will increase the experience for both parties. 
The $\mathrm{T}_{4}$ variable is rated at 3.5158 , the second highest in this scale indicating the importance of cultural factors, cultural exchanges of MICE tourists with the residents at the destination. MICE tourists will be attracted by the unique cultural characteristics of the destination. These unique features will stimulate visitors to find, exchange and integrate for their own experiences, and these experiences will help MICE visitors communicate, introduce to other visitors and promote the destination with these features. This is also a way to effectively market MICE tourism destinations. When MICE tourists attend MICE activities at the destination, the unique traditions and cultural characteristics of the ethnic community of Vietnam will be the next highlight for visitors to experience themselves in the cultural activities after visiting and exchanging experiences in the fields related to cultural and spiritual life or the traditional activities of ethnic groups.

Variable $T_{5}$ is rated 3.5053 as the third highest in the scale. This result shows that with the experience of living, learning, cultural understanding, lifestyle of diverse regions of MICE tourists, they can help increase the life quality of the destination residents by bringing habits, ways of living, and new jobs for the community. This resource will be promoted when MICE visitors interact with community members through cultural exchanges, dissemination of research results and social participation after MICE events. Organizations, business units that need to organize such programs along with MICE events will contribute to attracting destinations as well as contributing to the development of MICE tourism. When the organizers have programs for MICE visitors to participate in community activities in remote areas withdifficult living conditions, it is the MICE tourists who will bring residents here habits, ways of living, and new jobs, which can lead to better living habits, the quality of life of the people will be improved.

\section{Managerial implications related to organizational resources}

The results show that $\beta 0=0.231$, which is the third strongest impact factor. Therefore, the role of the organizer / sponsor of the event for the destination to develop MICE tourism is important. In the MICE tourism chain of Tingting et al. (2007), the event organizer is set at the start, which means if the event organizes hold or sponsor an event, the provision process begins. Besides conferences and seminars, the exhibitions andtrade fairs also play an increasingly important role in MICE tourism in promoting the image and brand name of local products and services of the organization.

The $\mathrm{O}_{1}$ variable is rated 3.5789 , the highest in the scale, indicating that many of the teammates chose to host their events at the destination, which also indicates that the MICE destination is on the list of some destinations chosento organize, but not yet reach the high rate. It is necessary to create a higher attractiveness at the destination, promote stronger unique features, attractivenesses in culture, history, natural scenery and the benefits that visitors will get when attending the event so as to attract more organizers to choose the destination to host the events. 
Table 10

Statistics of the means of organization resources

\begin{tabular}{lcr}
\hline & Mean & $\begin{array}{r}\text { Standard } \\
\text { deviation }\end{array}$ \\
\hline $\mathrm{O}_{1}$. Many businesses organize their events in Da Lat & 3.5789 & 0.93725 \\
$\mathrm{O}_{2}$. The relationship between the administration and & 3.5158 & 1.01256 \\
organizations facilitates the organization of MICE events & & \\
$\mathrm{O}_{3}$. Good coordination between local authorities and & & \\
businesses when organizing events in Da Lat & 3.4632 & 0.99800 \\
$\mathrm{O}_{4}$. Residents and volunteers contribute important & 3.4456 & 0.97216 \\
roles in events in Dalat & & \\
\hline
\end{tabular}

(Source: Results from data collection)

The $\mathrm{O}_{2}$ variable is rated 3.5158 , the second highest in this scale, indicating a good correlation between local government and event organizers. This will lead to event sponsored by the government, contributing to the success of the event.

$\mathrm{O}_{2}$ is a prerequisite for $\mathrm{O}_{3}$ to continue to be evaluated, with connection between local government and organizers, in a relationship built on the long-term interests of both sides. Local authorities will collaborate well with the organizers and vice versa to help the event succeed, benefits will be brought to both parties. Variable $\mathrm{O}_{3}$ has mean $=3,4632$, not very high, indicating that the coordination between the two sides is not high, may be because organizers find it unnecessary to coordinate with local authorities. But it is this less coordination which results in a number of resources such as the power of information dissemination, the relationship between local government and other units being wasted. Enhance coordination between the two sides, but actively from the organizers will take advantage of the intangible resources to create a successful event. It is necessary to continue to maintain and expand this relationship so that local authorities will have better support policies for both organizers and visitors.

The $\mathrm{O}_{4}$ variable in the study is estimated at 3.4456, meaning that the resident community only played a modest role in successfully organizing the event at the destination. As such, the policy of the event organizer should be of interest to the community by communicating, educating and facilitating the participation of the residents and volunteers in the event, they will understand benefit of the community better when organizing the event. That is, they will receive the resources of knowledge, experience from the visitors, and increase the relationship for their benefit. When they understand the benefits they will have, the contribution of the community will be more practical.

\section{Managerial implications related to MICE destination resources}

Countries having MICE tourism development recommend that a destination management organization be established that facilitates the creation of optimal business models and support to relevant areas. The establishment of destination management organizations in Vietnam will have the following contributions: 
- Establish a strong leadership, a solid financial management and ensure sustainable human resources. It will then provide strong support to both the public and private sectors and the community.

- Ensure operational processes from policy formulation, planning, having reliable andrigorous establishment of the cooperation of the parties in the support system and establishment of final supervision.

- Prepare a strong and effective information distribution system among stakeholders, local authorities and local communities to create a common vision of the community for tourism development.

- Facilitate the achievement of positive benefits and impacts for all stakeholders: visitors, experts, suppliers and residents in the region.

- Create sustainability from effective product-service management to influence the experience and satisfaction of MICE visitors.

- Stimulate the ideas to improve service quality.

Statistics of means of MICE destination resources in Table 11 show:

Firstly, the facilities provide visitors with accommodation $\left(\mathrm{D}_{2}=3.6526 ; \mathrm{D}_{3}=\right.$ $3.5684)$, conference rooms $\left(\mathrm{D}_{4}=3.7123\right)$, well-trained human resources $\left(\mathrm{D}_{5}=\right.$ $3.7474)$ are basically reached; the souvenir shop $\left(\mathrm{D}_{6}=3.6122\right)$ reflects that there are enough shops and souvenirs for tourists but not diversified and attractive. High-tech products manufactured locally are still lacking and not diversified. The content should be further improved, coordinated to improve the quality of service, thereby creating satisfaction for the organizers and MICE visitors.

Table 11

Statistics of the means of MICE destination resources

\begin{tabular}{lcr}
\hline & Mean & $\begin{array}{r}\text { Standard } \\
\text { deviation }\end{array}$ \\
\hline $\mathrm{D}_{1}$. Move in destination conveniently & 3.3754 & 0.63586 \\
$\mathrm{D}_{2}$. Enough rooms available for visitors to attend the event & 3.6526 & 0.90501 \\
$\mathrm{D}_{3}$. Many hotels are available from medium to high-end ones & 3.5684 & 0.91912 \\
$\mathrm{D}_{4}$. The conference room is sufficient to provide on demand & 3.7123 & 0.88891 \\
$\mathrm{D}_{5}$. Service staff with professional skills & 3.7474 & 0.92655 \\
$\mathrm{D}_{6}$. Many souvenir shops & 3.6211 & 0.86210 \\
$\mathrm{D}_{7}$. Many interesting places to visit & 3.7684 & 0.84068 \\
\hline
\end{tabular}

(Source: Results from data collection)

Secondly, the advantage of tourism resources is one of the attractions $\left(\mathrm{D}_{7}=\right.$ 3.7684). Respondents rate good for this point, the destination should continue to promote, and introduce to potential visitors to attract them to the destination.

Thirdly, the travel within the destination does not meet the expectations of the organizers and visitors, which means in order to get visitors to the right place, the desired time has not satisfied visitors $\left(\mathrm{D}_{1}=3.3754\right)$. It is necessary to have regular solutions to maintain, and upgrade transport infrastructure, develop forms of transportation to create more favorable conditions for tourists and resident 
communities, have plans on arranging and dividing the traffic in crowded days. Improving and developing the above characteristics, MICE tourism destination will promote the development of the tourism industry in general, MICE tourism in particular.

\section{Limitations of research and research direction}

Research can not avoid the specific limitations as follows:

Firstly, the study was conducted in the context of both theory and practice in Vietnam. There is no general model for MICE tourism development. Foreign researches in the field have led to narrower fields, while studies in Vietnam are not representative. Therefore, the proposed model may lack some other factors, which need to be further researched and expanded relevant criteria that will contribute to the consolidation of this research model. From there, more researches are needed to discover a number of factors, some new criteria to confirm the general model of both theory and practice.

Secondly, the study was conducted only at MICE Da Lat. The reality is that with different destinations, resources will vary in degree of mobilization, integration and distribution of resources. Therefore, it is necessary to expand the scope of accreditation and evaluation of theoretical models at MICE destinations such as Hanoi and Ho Chi Minh City, where there are often large and varied events.

Thirdly, the author's approach to research is primarily from the supply side. For a more general view at the MICE tourism market, further research is needed from the demand side, or from both supply and demand directions.

\section{References}

1. Acedo, F.J., Barroso, C., Galan, J.L., 2006. The resource-based theory: dissemination and main trends. Strategic Management Journal, 27:621-636.

2. Bennett, N., Lemelin, R.H., Johnston, M., 2010. Using the Social economy in Tourism: A study of National Park Creation and Community, Development in the Northwest Territories - Canada. Journal of Rural and Community Development 5, (1/2): 200-220.

3. Campiranon, K., Arcodia, C., 2008. Market Segmentation in Time of Crisis. Journal of Travel và Ôourism Marketing, 23: 151-161.

4. Cook, R.A., Yale, L.J. and Marqua, J.J., 2006. Tourism: The business of travel. Pearson Prentice Hall, New York.

5. Cooper, C., 2006. Knowledge management and tourism. Annals of Tourism Research, 33(1): 4764 .

6. Denicolai, S., Cioccarelli, G., Zucchella, A., 2010. Resource-based local development and networked core-competencies for tourism excellence. Tourism Management, 31(2):260-266.

7. Đinoviæ, L., 2010. Developmental prospects of MICE tourism in Montenegro. Selective Tourism, 5:17-31.

8. Dwyer, L., Mistilis, N., Forsyth, P., Rao, P., 2001. International price competitiveness of Australia's MICE industry. International Journal ofTourism Research, 3: 123.

9. Fodness, D., 1994. Measuring tourist motivation. Annals of Tourism Research, 21(3): 555-581.

10. González, M., Falcón, G., 2003. Competitive potential of tourism in destinations. Annals of Tourism Research, 30(3): 720-740.

11. Hussain, K., Ragavan, N.A., Kumar, J., Nayve, R.M., 2014. Micro-impacts and Benefits of Business Tourism in Malaysia: A Case Study of Kuala Lumpur Convention Centre. Asia-Pacific Journal of Innovation in Hospitality and Tourism, 1(3): 1-24. 
12. ICCA, 2016. The International Association Meetings Market.

13. Janakiraman, S., 2012. Growth and importance of the MICE industry. Asia-Pacific business và technology[Available at:http://www.biztechreport.com/story/1830-growth-and-importance-miceindustry].

14. Kotler, P., Jatusripitak, S., Maesincee S., 1997. The Marketing of Nations. A Strategic Approach to Building National Wealth. The Free Press, New York.

15. Le, Thai Son \& Ha, Nam KhanhGiao, 2014. Factors affecting MICE tourism in Dalat City. Journal of Economic Development, 6: 9-20.

16. Mitchell, R.K., Agle, B.R., Wood, D.J., 1997. Toward a Theory of Stakeholder Identification and Salience: Defining the Principle of Who and What Really Counts. The Academy of Management Review, 22(4): 853-886.

17. Nakatani, M.S.M., Teixeira, R.M., 2009. Resource-based View as a Perspective for Public Tourism Management Research: Evidence from Two Brazilian Tourism Destinations. BAR, Curitiba, 6(1): 62-77.

18. Nguyen, Chi Tranh, 2014. To the development of MICE in Vietnam. Economic and Forecasting Magazine, 25: 46-48.

19. Porter, M.E., 2001. Regions and the New Economies of Competition. Global city-regions, 139157.

20. Ramgulam, N., Mohammed, K. R., Raghunandan, M., 2012. Exploring the Dynamics of SocioCultural Sustainability in Trinidad's Mice Market. American International Journal of Contemporary Research, 2(6): 44-56.

21. Rogers, T., 2003. Conferences and Conventions: A global industry. Oxford UK: ButterworthHeinemann. FélagsvísindastofnunHáskólaÍslands.

22. Seebaluck, V.; Naidoo, P.; and Ramseook-Munhurrun, P., 2013. Meetings, Incentives, Conferences and Exhibitions as a Tourism development strategy in Mauritius. Global Conference on Business và Finance Proceedings. Institute for Business và Finance Research, 8(2): 354-364.

23. Tingting, L., Yujie, G., Mei, Z.M., 2007. An Analysis of Accessibility into MICE Industry Based on SSPAB Model. Tourism Tribune, 29: 77-83.

24. UNWTO, 2006. Measuring the Economic Importance of the Meetings Industry-Developing a Tourism Satellite Account Extension, Madrid: Spain

25. Viet Nam National Administration of Tourism, 2016. Annual Vietnam Tourism Report, Hanoi.

26. Wernerfelt, B., 1984. A resource-based view of the firm. Strategic Management Journal 5(2): $171-180$.

Ha Nam Khanh Giao - Le Thai Son: University of Finance - Marketing, Vietnam 